\title{
Treatment of waste stabilization pond effluent using natural zeolite for irrigation potential
}

\author{
Kulyash Meiramkulova ${ }^{1}$, Timoth Mkilima ${ }^{2, *}$, Aliya Kydyrbekova ${ }^{3, *}$, Elmira Bukenova ${ }^{4}$, Abdilda Meirbekov ${ }^{5}$, \\ Gulnur Saspugayeva ${ }^{1}$, Gulmira Adilbektegi ${ }^{1}$, Kulzhan Beisembayeva ${ }^{6}$, and Gaukhar Tazhkenova ${ }^{6}$
}

1 Department of Environmental Engineering and Management, Faculty of Natural Sciences, L.N. Gumilyov Eurasian National University, Satpayev street 2, 010000, Nur-Sultan, Kazakhstan; kuleke@gmail.com (K.M); gulnur.er@mail.ru (G.S); adilbekova.gulmira@yandex.ru (G.A)

2 Department of Civil Engineering, Faculty of Architecture and Construction, L.N. Gumilyov Eurasian National University, Satpayev street 2, 010000, Nur-Sultan, Kazakhstan; tmkilima@gmail.com (T.M)

3 Department of Management, Faculty of Economics,L.N. Gumilyov Eurasian National University, Satpayev street 2, 010000, Nur-Sultan, Kazakhstan; aliyafromkz@gmail.com (A.K)

4 Department of Agronomiy,Technical Faculty,Zhetysu University named after I.Zhansugurov, Zhansugurov street 187A,Taldykorgan,Kazakhstan; bukenova@bk.ru (E.B)

5 Department of Enviroment and Chemistry, University of Hosa Ahmet Yesevi, , B.Sattarhanov str. 29,161200, Turkestan , Kazakhstan; abdilda@mail.ru (A.M)

6 Department of Chemistry, Faculty of Natural Sciences, L.N. Gumilyov Eurasian National University, Satpayev street 2, 010000, Nur-Sultan, Kazakhstan; beisembaeva64@mail.ru (K.B); gaukhar-1970@mail.ru (G.T)

* Correspondence: aliyafromkz@gmail.com (A.K), tmkilima@gmail.com (T.M)

\begin{abstract}
Direct utilization of treated effluent from natural treatment systems for irrigation can be challenging on sensitive plants due to high levels of salinity. Post-treatment of such an effluent prior to its applicability in irrigation can be of significant importance. In this study, the wastewater from a natural treatment plant was treated using a lab-scale filtration system with zeolite as a filter material. Three different column depths $(0.5 \mathrm{~m}, 0.75 \mathrm{~m}$, and $1 \mathrm{~m})$ were used to investigate the effect of column depth on the treatment efficiency of the media. The suitability of the raw wastewater and the treated effluent from each column for irrigation purposes was investigated. The water quality parameters investigated were; electrical conductivity (EC), total dissolved solids (TDS), sodium $(\mathrm{Na}+)$, calcium $(\mathrm{Ca} 2+)$, and magnesium $(\mathrm{Mg} 2+)$. From the analysis results, it was observed that the column depth had a significant influence on the removal efficiency of the pollutants. Where the removal efficiency was observed to be increasing with the increase in the column depth. The highest removal efficiency $(94.58 \%)$ was achieved from the combination of electrical conductivity and $1 \mathrm{~m}$ column depth, while the lowest removal efficiency (10.05\%) was observed from the combination of calcium and $0.5 \mathrm{~m}$ column depth. The raw wastewater fell mostly into a "very high" hazard, which is class four (C4) based on electrical conductivity and class four (S4) based sodium adsorption ratio; making it unsuitable for irrigation purposes. However, the status improved after the treatment using different column depths.
\end{abstract}

Keywords: natural wastewater treatment; zeolites; sodium adsorption ratio; salinity; irrigation

\section{Introduction}

Effluent generated from natural wastewater treatment systems such as waste stabilization ponds is usually saline compared to freshwater due to high concentration levels of dissolved salts. Generally, natural treatment systems are those having little to no dependence on mechanical elements and chemicals to support wastewater purification. The systems mostly depend on plants and microorganisms such as bacteria to decompose and neutralize pollutants in wastewater [1-3].

Unfortunately, the linked high concentrations of salinity in the effluent could pose a significant threat to soil quality and plant growth at large upon its direct application in 
irrigation without being properly treated [4]. In general, soil salinization is regarded to be among the major threats to plant growth and affecting the agricultural sector in many parts of the world [5,6]. It is also important to note that, natural treatment systems are the most widely used technologies for wastewater treatment in the world [7-9], generating huge volumes of effluents every day. With the fact that freshwater is a vital and scarce resource [10], the reuse of effluents from natural treatment systems becomes an ideal solution for irrigation purposes.

However, studies have observed that crops grown on soils with high electrical conductivity (EC) can significantly reduce their yield [11]. Carbonates, chlorides, sulfates, and bicarbonates of sodium, potassium, magnesium, and calcium are among the salts that can be found in the effluent from waste stabilization ponds. Moreover, when the soil is more saline-sodic, the growth is affected by a combination of high alkalinity, high sodium $\left(\mathrm{Na}^{+}\right)$, as well as high salt concentration [12]. Therefore, it is always necessary to differentiate between soil salinization and soil sodicity. However, salt tolerance among plants differs from one plant to another $[13,14]$.

Generally, salt tolerance can be defined as the state at which a plant can grow and complete its life cycle on a substrate with high concentrations of levels of soluble salt [15]. Halophytes is the name given to plants that can withstand high concentrations levels of salt in the rhizosphere and grow well [16,17]. There are many crops with low salinity tolerance including rice (Oryza sativa L.) that has been observed to be highly susceptible to the rhizosphere salinity than other cereals [18]. From rice, it has been observed that high sensitivity mainly occurs at the vegetative and reproductive stages [19].

Among the challenges of salt, accumulation is the tendency of reducing the ability of the plants to uptake water and nutrients, resulting in osmotic or water-deficit stress. For sensitive plants, salt causes injury of the young photosynthetic leaves as well as accelerating their senescence. This is due to the fact that the Na+ cation accumulated in cell cyto-sol results in affecting the transpiration process of leaves [20]. To determine the suitability of water for use in irrigation, the sodium adsorption ratio (SAR) has been widely applicable as an indicator based on the concentrations of the main alkaline and earth alkaline cations present in the water [21]. Apart from EC and $\mathrm{Na}^{+}$, other parameters such as total dissolved solids (TDS), magnesium ion $\left(\mathrm{Mg}^{2+}\right)$, and calcium ion $\left(\mathrm{Ca}^{2+}\right)$ are also important to investigate the suitability of water for irrigation.

Therefore, to make the saline effluent from waste stabilization ponds reusable in irrigation, many treatment technologies have been introduced into the water industry. The technologies include the use of medium filtration and membrane filtration, cation exchange, electrodialysis, sorption, and electrochemical treatments. However, issues related to high capital costs especially due to energy consumption have hindered their application in wider regions [22].

This phenomenon brings significant importance to investigate the potential applicability of low-cost approaches for the treatment of biological treatment plant effluent with respect to irrigation purposes. The application of natural or synthetic zeolites as ion exchangers and adsorbents is regarded as among the relatively economical solutions for treating and reusing wastewater of high salinity [23]. Zeolites as a filter material provide one of the economical technologies and have been widely used in the field of water treatment as ion exchangers and adsorbents [24,25].

In this study, the potential applicability of zeolites on treating the effluent from a waste stabilization pond for irrigation purposes of low salinity tolerance plants is investigated. Three different column depths $(0.5 \mathrm{~m}, 0.75 \mathrm{~m}$, and $1 \mathrm{~m})$ are used the investigate the influence of column depth on the treatment efficiency of zeolite. Then the effluent from each column is investigated for its potential applicability in irrigation, especially for sensitive plants.

\section{Materials and Methods}

\subsection{Case study description, analytical methods, and wastewater characteristics}


The wastewater samples used in this study were collected from the Vingunguti wastewater stabilization ponds in Dar es Salaam, Tanzania, approximately $7.2 \mathrm{~km}$ from the city Centre (latitude: 650'17.20"S, longitude: 39¹4'8.62"E).

A number of water quality parameters were investigated in this study, including; EC, $\mathrm{Na}^{+}$, TDS, $\mathrm{Mg}^{2+}$, and $\mathrm{Ca}^{2+}$. The selection of the parameters is based on their significance in determining water suitability for irrigation purposes. In general, $\mathrm{Na}^{+}$was measured using the Sodium-Ion Selective Electrode Method [26], while both $\mathrm{Mg}^{2+}$ and $\mathrm{Ca}^{2+}$ in water samples were measured using the Ethylenediaminetetraacetic Acid (EDTA) Method[27], with $\mathrm{Na}_{2}$ EDTA 0.05, Acetylacetone, Tris(hydroxymethyl)-aminomethane (TRIS), Distilled Water and Electrolyte solution L300 as reagents. TDS and EC were determined using the TDS Meter Digital Water Tester (Lxuemlu, Shenzhen, China).

Table 1 presents a summary of the raw wastewater characteristics in terms of minimum (Min), maximum (Max) median, arithmetic mean (AM), and standard deviation (STD). A maximum EC concentration of $4224 \mu \mathrm{S} / \mathrm{cm}$ was observed from the raw wastewater, with an average concentration of $2478.1 \mu \mathrm{S} / \mathrm{cm}$.

Table 1. Raw wastewater characteristics

\begin{tabular}{cccccc}
\hline Parameter & Min & Max & Median & AM & STD \\
\hline EC & 1001 & 4224 & 2251 & 2478.10 & 731.975 \\
TDS & 996 & 2284 & 1602 & 1622.20 & 332.429 \\
$\mathrm{Na}^{+}$ & 115.5 & 145.7 & 133.8 & 131.93 & 9.226 \\
$\mathrm{Mg}^{2+}$ & 8.7 & 22.5 & 15.1 & 14.61 & 4.095 \\
$\mathrm{Ca}^{2+}$ & 6.2 & 14.3 & 8.85 & 9.30 & 2.344 \\
\hline
\end{tabular}

$\mathrm{EC}$ in $\mu \mathrm{S} / \mathrm{cm}$, all other parameters in $\mathrm{mg} / \mathrm{L}$

\subsection{Experimental setup}

Three different fixed-bed columns with $0.5 \mathrm{~m}, 0.75 \mathrm{~m}$, and $1 \mathrm{~m}$ depths were used to investigate the influence of column depth in the treatment efficiency of natural zeolite (Figure 1). The column containers are of Polyvinyl chloride (PVC) material with approximately $5.08 \mathrm{~cm}$ in diameter. All three columns were packed with natural zeolite adsorbents (clinoptilolite) composed of a microporous arrangement of silica and alumina tetrahedra with an average particle size of $1.5 \mathrm{~mm}$ (FM Stock and Supplies, Kenmare, Gauteng, South Africa).

To allow equal distribution of flow in the columns, the top surfaces of the columns were covered by perforated plates with evenly distributed holes. $100 \mathrm{~L}$ storage drum was used to feed the columns at a controlled rate of $0.0035 \mathrm{~L} / \mathrm{s}$. To maintain all the solids in suspension, the wastewater was slowly and continuously stirred. The Wet-packing approach of the porous medium was used with the purpose of minimizing layering and air entrapment inside the filing. All three columns were mounted vertically, and glass wool was used at the bottom of the column acting as supporting material of the adsorbent bed. After packing the column, deionized water was passed through the column for some time, followed by the introduction of the feed water. The filtrate samples were collected at a regular time interval. All the experiments were carried out at room temperature (20 to $25^{\circ} \mathrm{C}$ ). 


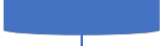

Natural

zeolite

Wastewater

Treated

effluent

\section{Not drawn to scale}



Figure 1. Experimental setup

\section{Statistical methods}

Correlation analysis was among the approaches used to analyze results from the experiments. Correlation matrices were developed to evaluate the strength of the relationship among the studied parameters. A high correlation indicates that two or more variables have a strong relationship with each other. While a weak correlation provides an indication that the variables are hardly related. Table 2 provides a summary of the interpretation of the correlation indices used in this study.

Table 2. Interpretation of the correlation coefficients

\begin{tabular}{cc}
\hline Range of correlation coefficient & Strength of relationship \\
\hline $0-0.29$ & Weak \\
$0.3-0.49$ & Moderate \\
$0.5-0.69$ & Strong \\
$0.7-1$ & Very strong \\
\hline
\end{tabular}

Apart from the correlation matrices, box and whisker plots were used to evaluate data distributions among the water quality parameters. The evaluation is based on the distribution of numerical data and skewness through data quartiles (percentiles) and averages. In general, box plots show the five-number summary of a set of data: the minimum score, first (lower) quartile, median, third (upper) quartile, and maximum score. In this study; EC, $\mathrm{Na}, \mathrm{Mg}, \mathrm{Ca}$, and TDS were analyzed using box and whisker plots. 
The salinity hazard zones based on electrical conductivity (EC) were classified into four classes; class one (C1) class two (C2), class three (C3), and class four (C4), ranging from low salinity (C1) to very high salinity (C4). Table3 provides a summary of the salinity hazard zones based on EC with their interpretations in terms of usability.

Table 3. Salinity Hazard Zones: based on electrical conductivity

\begin{tabular}{ccc}
\hline Water class & EC $(\mu \mathrm{S} / \mathrm{cm})$ & Definition \\
\hline C1 - Low salinity & $0-250$ & Water can be used safely \\
C2 - Medium salinity & $250-750$ & Water can be used with moderate leaching \\
C3 - High salinity & $750-2250$ & Water can be used for irrigation purposes with \\
& & some management practices \\
C4 - Very high & $2250-5000$ & Water cannot be used for irrigation purposes \\
\hline
\end{tabular}

Table 4 provides a summary of the salinity hazard zones based on Sodium adsorption ratio (SAR) with their interpretations in terms of usability. The salinity hazard zones based on SAR were also classified into four classes and used in the Wilcox diagrams; class one (S1) class two (S2), class three (S3), and class four (S4) ranging from low sodium hazard (S1) to very high sodium hazard (S4).

Table 4. Sodium Hazard Zones: based on Sodium Adsorption Ratio lines

\begin{tabular}{ccc}
\hline Water class & SAR & Definition \\
\hline S1 low sodium hazard & $0-10$ & Little or no hazard \\
S2 medium sodium hazard & $(10-18)$ & Appreciable hazard but can be used with \\
& & appropriate management \\
S3 High sodium hazard & $18-26$ & Unsatisfactory for most of the crops \\
S4 Very high sodium \\
hazard
\end{tabular}

SAR can be defined as an index used to define the effect of sodium concentration in a sample in relation to calcium and magnesium. More specifically, the SAR index is achieved by diving the square root of $1 / 2$ of the calcium plus magnesium concentrations. Equation 1 provides a summary of the formula used in the computations of SAR [28].

$$
S A R=\frac{N a^{+}}{\sqrt{\frac{C a^{2+}+M g^{2+}}{2}}}
$$

Furthermore, Wilcox diagrams were plotted from the raw wastewater, effluent from $0.5 \mathrm{~m}, 0.75 \mathrm{~m}$, and $1 \mathrm{~m}$ zeolite columns. By definition, the Wilcox plot is a semi-log scatter plot of the "sodium hazard" (SAR) on the Y-axis versus the "salinity hazard" (EC) on the $\mathrm{X}$-axis. It has to be noted that, the EC is plotted by default in a log scale. The treated effluent suitability for irrigation mainly depends on the concentration of total salinity and sodium related to other ions [29]. Therefore, the diagrams were used to evaluate the risk levels in the raw wastewater and the treated effluent from the three columns.

\section{Results and discussion}

The analysis of the water samples before and after the treatment was successfully executed. In the raw wastewater samples, the average EC concentration was $2478.1 \mu \mathrm{S} / \mathrm{cm}$, while that of TDS was $1622.20 \mathrm{mg} / \mathrm{L}$. The EC concentration in the raw wastewater falls in 

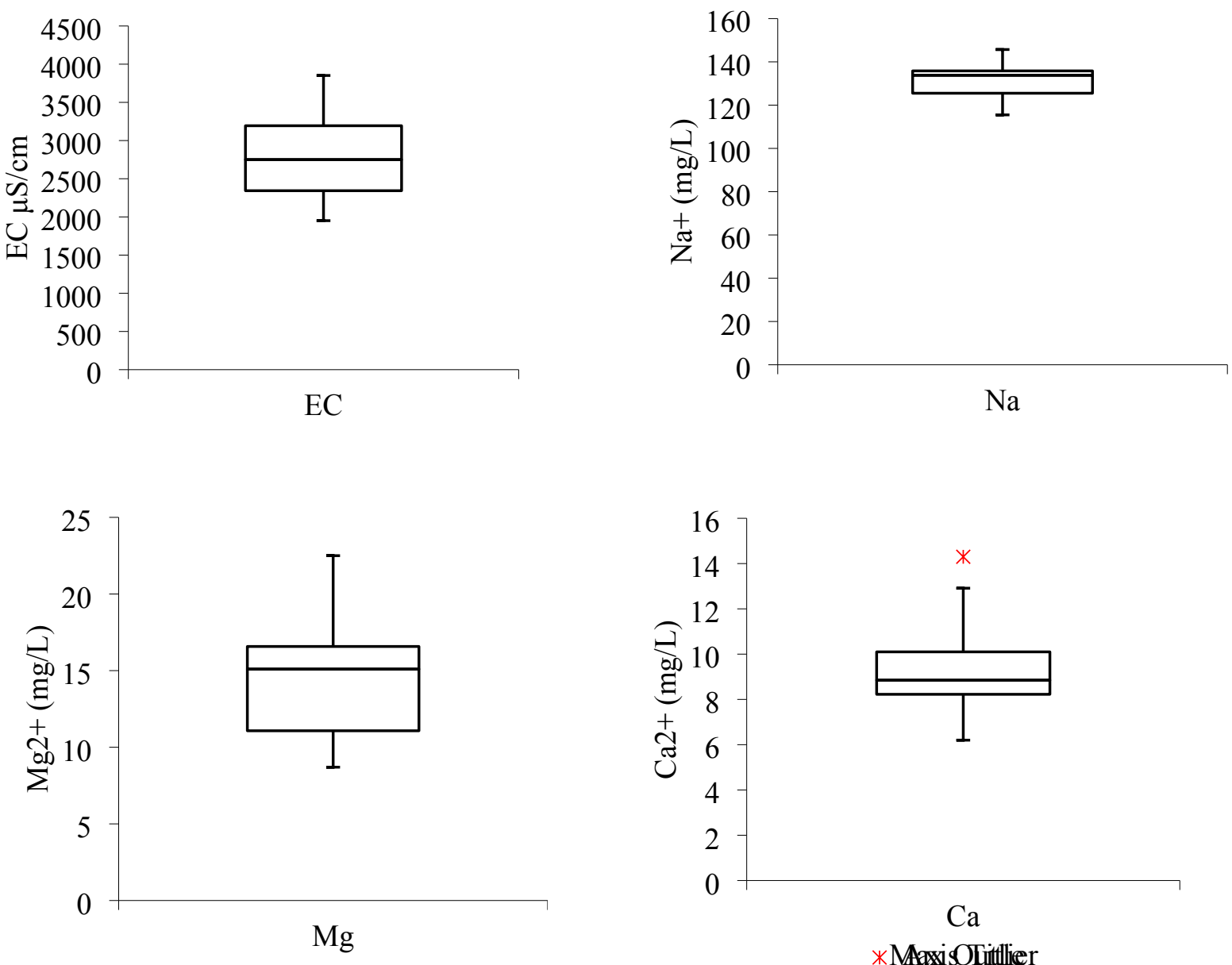




Figure 2. Boxplots from raw wastewater (a) EC (b) $\mathrm{Na}^{+}$(c) $\mathrm{Mg}^{2+}$ (d) $\mathrm{Ca}^{2+}$ (e) TDS

A correlation matrix for the studied water quality parameters in raw wastewater was developed to evaluate the strength of the relationship among them. From Table 5, it can be observed that the general correlation among the parameters ranging from a strong to a very strong relationship. The highest correlation index of 0.966002 was achieved between $\mathrm{Na}$ and EC, followed by 0.945631 between TDS and Na. Also, a very strong correlation can be observed between TDS and EC with a correlation index of 0.944682 . The lowest correlation index can be observed between the $\mathrm{Mg}^{2+}$ and $\mathrm{Na}^{+}$with a correlation index of 0.598734 . However, the index between $\mathrm{Mg}^{2+}$ and $\mathrm{Na}^{+}$falls under a strong relationship.

In the literature, other studies have also observed a very strong relationship between TDS and EC to the point of recommending the EC to estimate TDS based on the linear relationship as shown in Equation 2 [30,31]. With the fact that TDS measurement is considered to be a time-consuming process, simplicity is often estimated from EC assuming TDS are predominantly ionic species of low enough concentration to produce a linear TDS-EC relationship [32].

$$
\operatorname{TDS}\left(\frac{m g}{L}\right)=K_{e} \times E C\left(\frac{\mu \mathrm{S}}{\mathrm{cm}}\right)
$$

Where; $\mathrm{K}_{\mathrm{e}}$ is a proportionality constant ranging from 0.54 to 1.1 .

According to Thirumalini and Joseph [33], that investigated the correlation between EC and TDS in natural waters, it was observed that the correlation index between TDS and EC was 0.63 for samples taken from pollution-free residential areas as well as ranging from 0.59 to 0.93 for samples taken from the textile industrial belt. Therefore, the general strong correlation between TDS and EC observed in the literature agrees with the results obtained from this study.

Table 5. Correlation matrix from raw wastewater

\begin{tabular}{cccccc}
\hline & $\mathrm{EC}$ & $\mathrm{Na}^{+}$ & $\mathrm{Mg}^{2+}$ & $\mathrm{Ca}^{2+}$ & $\mathrm{TDS}$ \\
\hline $\mathrm{EC}$ & 1 & & & & \\
$\mathrm{Na}^{+}$ & 0.966002 & 1 & & & \\
$\mathrm{Mg}^{2+}$ & 0.650596 & 0.598734 & 1 & & \\
$\mathrm{Ca}^{2+}$ & 0.837318 & 0.766448 & 0.725882 & 1 & \\
$\mathrm{TDS}$ & 0.944682 & 0.945631 & 0.611418 & 0.865351 & 1 \\
\hline
\end{tabular}

From Tables 6 to 8 , it can be observed that, when the depth was increased from 0.75 $\mathrm{m}$ to $1 \mathrm{~m}$, there was slight difference in terms of EC and TDS removal in the wastewater. 
The average EC concentration from the $0.75 \mathrm{~m}$ column depth was $487.85 \mu \mathrm{S} / \mathrm{cm}$, while from $1 \mathrm{~m}$ column depth, the average EC concentration was $378.51 \mu \mathrm{S} / \mathrm{cm}$. Also, the average TDS concentration from the $0.75 \mathrm{~m}$ column depth was $134.36 \mu \mathrm{S} / \mathrm{cm}$, while that of $1 \mathrm{~m}$ column depth was $130.163 \mu \mathrm{S} / \mathrm{cm}$. The phenomenon suggests that, the treatment approach has a gradual removal efficiency as the column depth increases from $0.75 \mathrm{~m}$ to $1 \mathrm{~m}$.

Table 6. Water quality characteristics from $0.5 \mathrm{~m}$ column depth effluent

\begin{tabular}{cccccc}
\hline Parameter & Min & Max & Median & Mean & STD \\
\hline EC & 901 & 2403 & 1202 & 1352.898 & 432.395 \\
TDS & 980 & 1282 & 1101 & 1107.3 & 102.363 \\
$\mathrm{Na}$ & 86.6 & 127.6 & 105.65 & 106.38 & 11.295 \\
$\mathrm{Mg}$ & 6.4 & 10.6 & 9 & 8.87 & 1.416 \\
$\mathrm{Ca}$ & 4.4 & 10.3 & 8.95 & 8.365 & 1.918 \\
\hline
\end{tabular}

Table 7. Water quality characteristics from $0.75 \mathrm{~m}$ column depth effluent

\begin{tabular}{cccccc}
\hline Parameter & Min & Max & Median & Mean & STD \\
\hline EC & 310 & 662 & 501 & 487.8531 & 98.452 \\
TDS & 88 & 239.5 & 123 & 134.36 & 42.892 \\
$\mathrm{Na}$ & 52.9 & 72.8 & 63.75 & 64.07 & 7.182 \\
$\mathrm{Mg}$ & 2.06 & 10.4 & 6.45 & 6.51 & 2.383 \\
$\mathrm{Ca}$ & 4.5 & 11.6 & 7.6 & 7.81 & 2.463 \\
\hline
\end{tabular}

Table 8 . Water quality characteristics from $1 \mathrm{~m}$ column depth effluent

\begin{tabular}{cccccc}
\hline Parameter & Min & Max & Median & Mean & STD \\
\hline EC & 307 & 442.1 & 388.5 & 378.51 & 44.474 \\
TDS & 94 & 162 & 137 & 130.163 & 28.752 \\
$\mathrm{Na}$ & 8.5 & 45.6 & 22.55 & 20.75 & 10.478 \\
$\mathrm{Mg}$ & 0.9 & 4.6 & 2.3 & 2.5 & 1.134 \\
$\mathrm{Ca}$ & 2.5 & 8.5 & 5.1 & 5.15 & 1.734 \\
\hline
\end{tabular}

From Figure 3, the EC, $\mathrm{Na}^{+}$and TDS boxplots, the median line closer to the upper quartile with an indication that the distribution of $\mathrm{EC}, \mathrm{Na}^{+}$, and TDS data in the treated effluent using the $1 \mathrm{~m}$ column of zeolite is considered to be "negatively skewed". While that of $\mathrm{Mg}^{2+}$ is observed to be closer to the middle, indicating that the $\mathrm{Mg}^{2+}$ data distribution was symmetric or normal. From the $\mathrm{Ca}^{2+}$ boxplot, the median line is seen to be closer to the upper quartile with an indication that the distribution of $\mathrm{Ca}^{2+}$ data in the treated effluent using the $1 \mathrm{~m}$ column of zeolite is considered to be "negatively skewed". This means the $\mathrm{Ca}^{2+}$ data constituted a higher frequency of low concentration values than the high concentration values. 

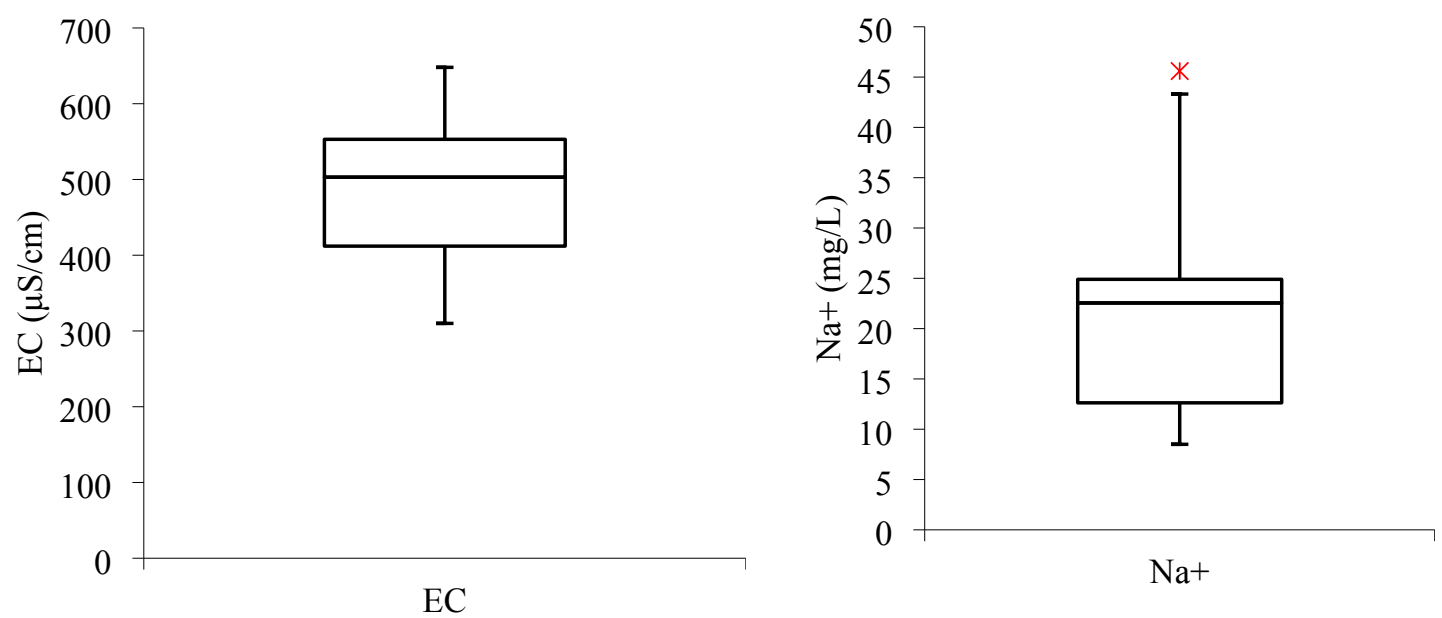

*Max Outlier

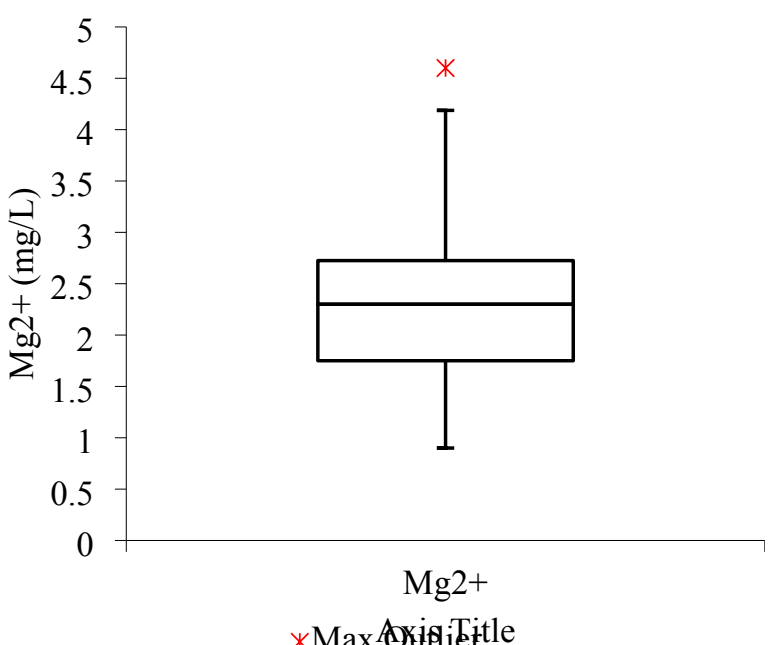

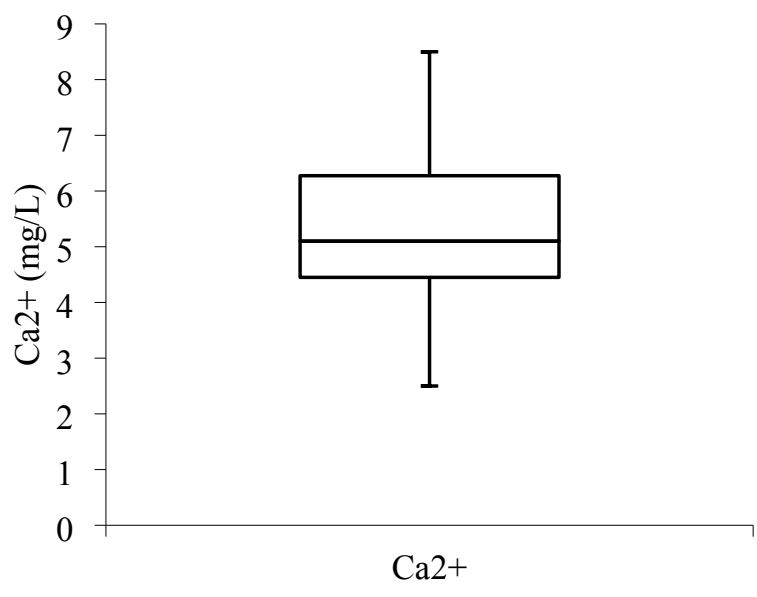

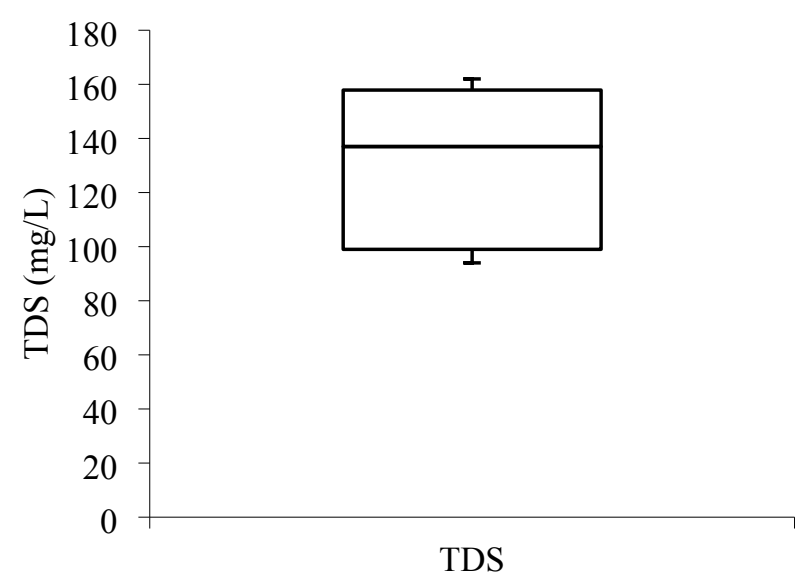

Figure 3. Boxplots from $1 \mathrm{~m}$ column effluent (a) $\mathrm{EC}$ (b) $\mathrm{Na}^{+}$(c) $\mathrm{Mg}^{2+}$ (d) $\mathrm{Ca}^{2+}$ (e) TDS

The removal efficiency of the studied parameters was observed to be significantly affected by the column depths; the more the column depth, the higher the removal efficiency. The highest removal efficiency (94.58\%) was achieved from the combination of EC and $1 \mathrm{~m}$ column depth. This was followed by a removal efficiency of $91.98 \%$ from the combination of TDS and $1 \mathrm{~m}$ column depth. The lowest removal efficiency can be observed from the combination of $\mathrm{Ca}^{2+}$ and $0.5 \mathrm{~m}$ column depth. In the literature, natural zeolite has also been observed to be highly efficient in terms of TDS removal. According to [34], which investigated the treatability of brackish groundwater by zeolite filtration in 
Sumur Tua Wonocolo, Kedewan, Bojonegoro, East Java, a TDS removal efficiency of up to $84 \%$ was achieved.

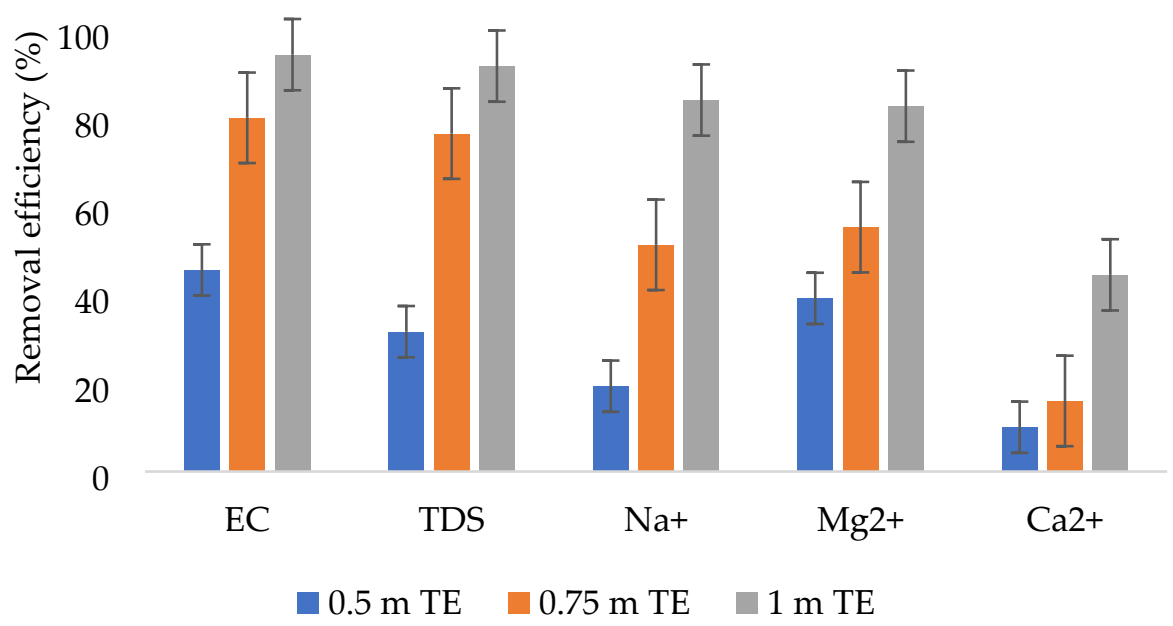

Figure 4. Removal efficiencies

From Figure 5, it can be observed that the raw wastewater falls under high (C3) to very high (C4) hazards based on the EC. Approximately $68 \%$ of the values fall under the very high hazard while $32 \%$ fall under the high hazard category. While, based on the SAR, the raw wastewater falls from low (S1) to very high (S4), with the majority of the values falling under medium (S2) and high (S3). The general phenomenon suggests that raw wastewater is not recommended for irrigation purposes especially for low-salt-tolerance plants based on EC and unsatisfactory for most of the crops based on SAR.

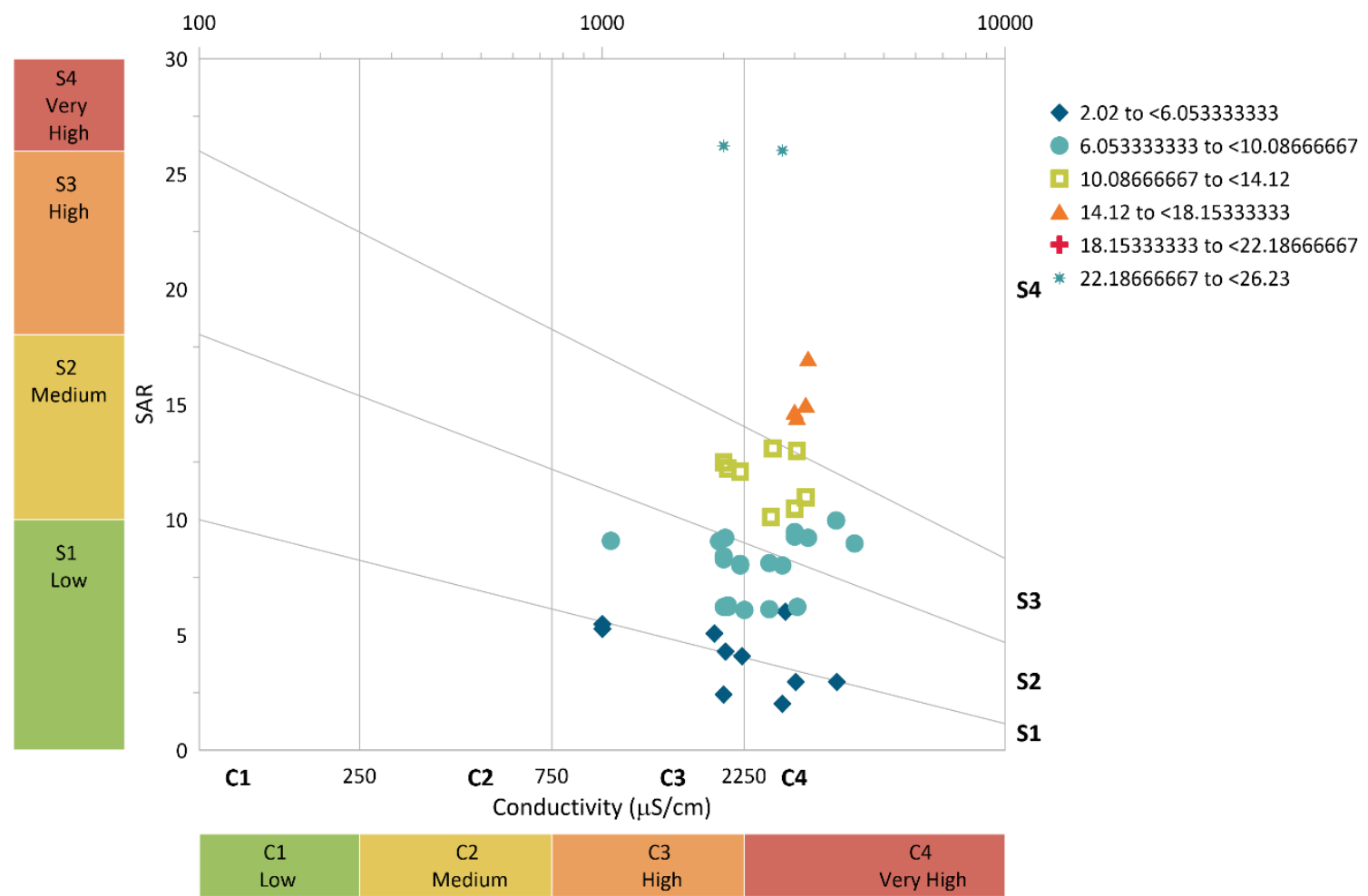

Figure 5. Salinity hazard from raw wastewater 
From Figure 6, it can be observed that the treated effluent from $0.5 \mathrm{~m}$ column of zeolite falls under high (C3) to very high (C4) hazard based on the EC. Approximately $97 \%$ of the values fall under the high hazard while 3\% fall under the very high hazard category. While, based on the SAR, the treated effluent from $0.5 \mathrm{~m}$ zeolite column falls under low (S1) to high (S4), with the majority of the values falling within medium (S2) hazard. The general phenomenon suggests that the treated effluent from the $0.5 \mathrm{~m}$ column is under appreciable hazard but can be used with appropriate management based on SAR and can be used for irrigation purposes with some management practices based on EC.

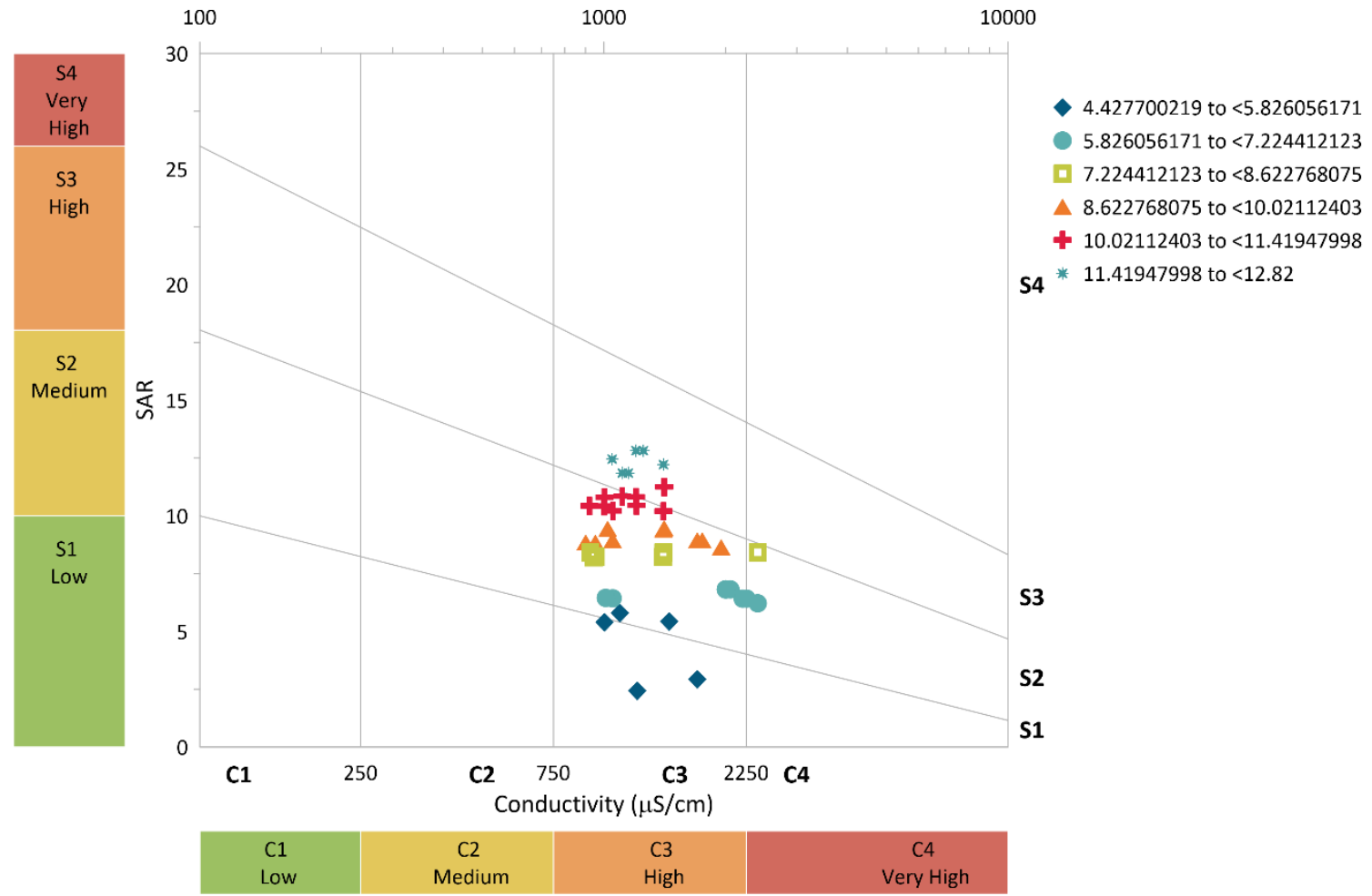

Figure 6. Salinity hazard from $0.5 \mathrm{~m}$ column effluent

From Figure 7, it can be observed that the treated effluent from the $0.75 \mathrm{~m}$ zeolite column falls under medium (C2) hazard based on the EC. Almost $100 \%$ of the values fall under medium hazard. While, based on the SAR, the treated effluent from $0.75 \mathrm{~m}$ falls under low (S1), with very few values getting close to medium (S2). The general phenomenon suggests that the treated effluent from a $0.75 \mathrm{~m}$ column can be used for crop irrigation purposes with little or no hazard based on SAR and can be used with moderate leaching based on EC. 


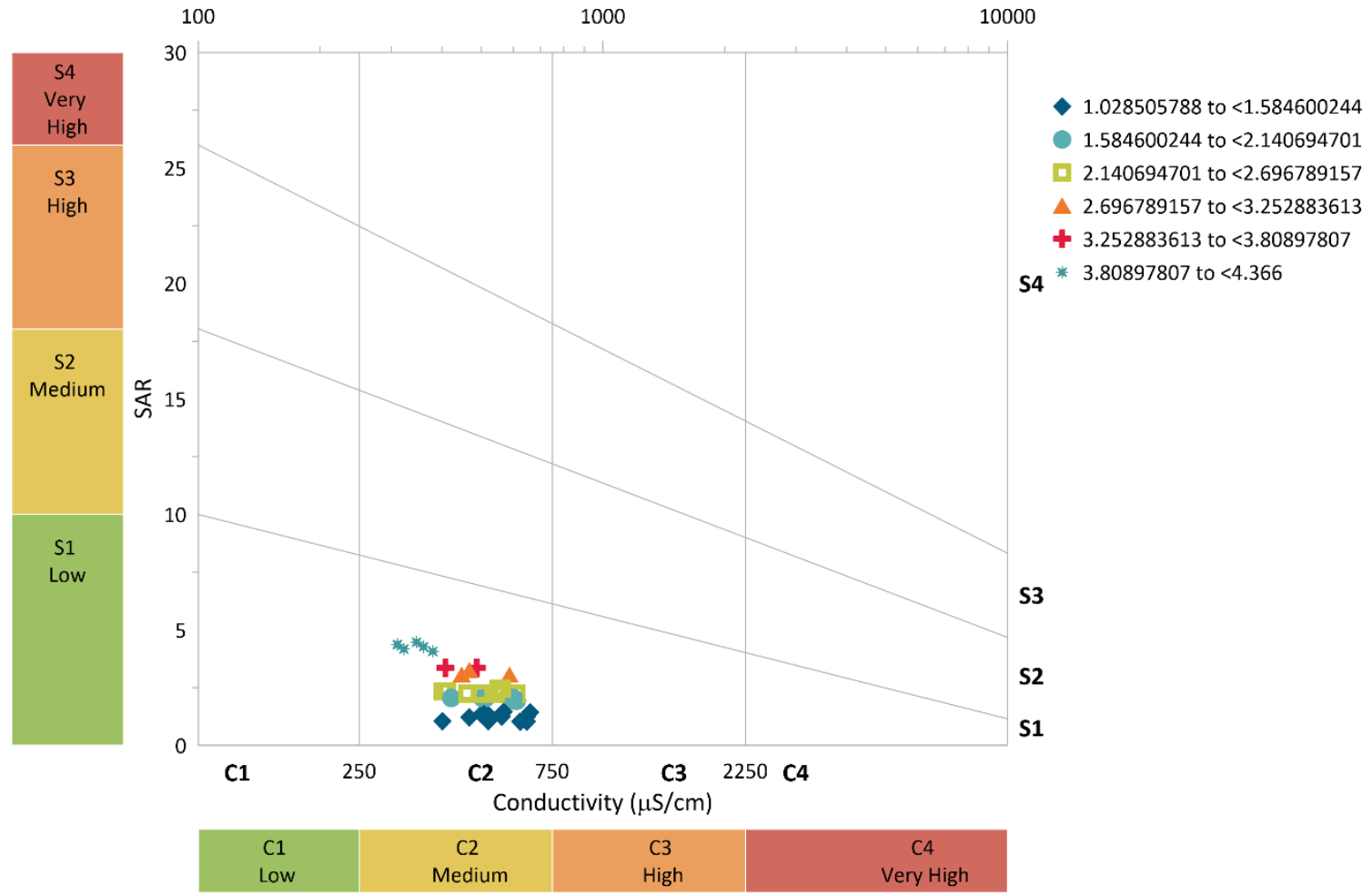

Figure 7. Salinity hazard from $0.75 \mathrm{~m}$ column effluent

From Figure 8, it can be observed that the treated effluent from the $1 \mathrm{~m}$ zeolite column falls under a low (C1) hazard based on the EC. While, based on the SAR, the treated effluent from $1 \mathrm{~m}$ column under low (S1), with very little values getting close to medium (S2). The general phenomenon suggests that the treated effluent from the $1 \mathrm{~m}$ column can be used for crop irrigation purposes with little or no hazard based on SAR and can be used safely based on EC.
100
1000
10000
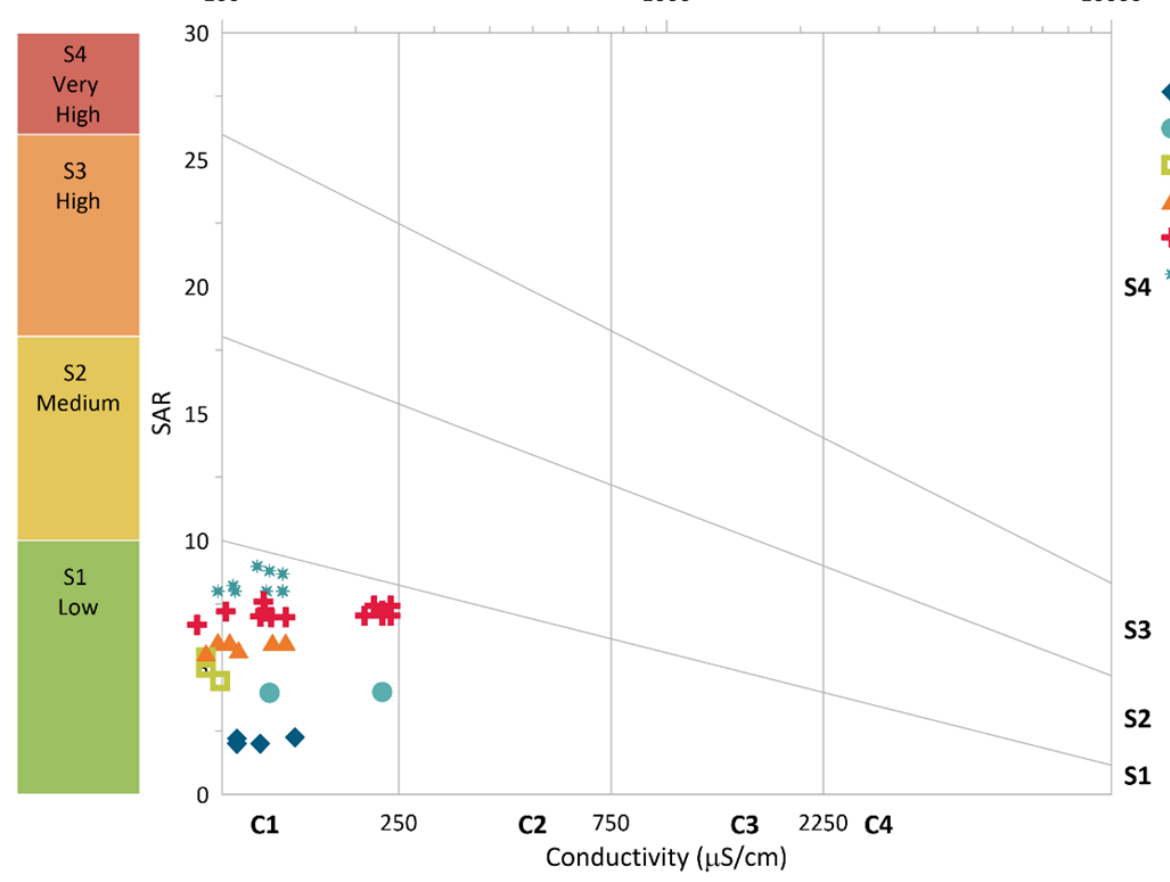

2.002408189 to $<3.167285009$

3.167285009 to $<4.332161829$

口 4.332161829 to $<5.497038649$

$\Delta 5.497038649$ to $<6.661915469$

+6.661915469 to $<7.82679229$

S4 * 7.82679229 to $<8.992$

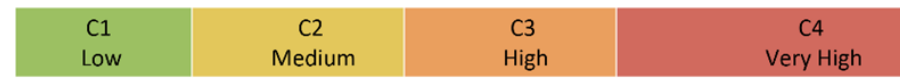

Figure 8 . Salinity hazard from $1 \mathrm{~m}$ column effluent 


\section{Conclusions}

In this study, the potential applicability of zeolites on treating the effluent from a waste stabilization pond for irrigation purposes has been investigated with three different column depths. A correlation among the studied parameters was observed with the highest correlation index of 0.966002 achieved between $\mathrm{Na}^{+}$and EC, followed by 0.945631 between TDS and $\mathrm{Na}^{+}$. Also, the results showed that the pollutants removal efficiency increased with the increase in column depth. Among the studied parameters, the highest removal efficiency (94.58\%) was achieved from the combination of EC and $1 \mathrm{~m}$ column depth, while the lowest removal efficiency $(10.05 \%)$ was observed from the combination of $\mathrm{Ca}^{2+}$ and $0.5 \mathrm{~m}$ column depth. From the hazard analysis, the raw wastewater generally fell into the "very high" hazard class based on both EC and SAR. In that matter, the raw wastewater has to be treated further prior to its application for irrigation purposes. However, the status improved after the treatment using different column depths. In that matter, the results from this study revealed further that, it is always important to investigate the quality of effluent from natural treatment systems before subjecting it to any sort of irrigation. Moreover, the use of zeolite can provide one of the efficient approaches to improve the effluent and make it suitable for irrigation.

Author Contributions: Conceptualization, T.M; methodology; software, T.M. and K.M., validation, K.M., G.A., and G.S.; formal analysis, E.B.and A.K.; investigation, T.M.; resources, K.M.; data curation, K.M., A.M., G.T., K.B., T.M., and To.M.; writing-original draft preparation, T.M., writing-review and editing T.M. and K.M.; visualization.; supervision, K.M.; project administration K.M., All authors have read and agreed to the published version of the manuscript.

Funding: This research was funded by the Ministry of Education and Science, the Republic of Kazakhstan to support "Reducing the technogenic impact on water resources with using water recycling technology", № BR05236844 /215 for 2018- 2020 years.

Data Availability Statement: Not applicable

Conflicts of Interest: The authors declare no conflict of interest. The funders had no role in the design of the study; in the collection, analyses, or interpretation of data; in the writing of the manuscript, or in the decision to publish the results.

\section{References}

1. El Gohary R. Low-cost natural wastewater treatment technologies in rural communities using Instream Wetland, Moringa Oleifera, and Aeration Weirs - A comparative study. Sánchez J, editor. Cogent Eng. 2020;7: 1846244. doi:10.1080/23311916.2020.1846244

2. Verbyla ME, Cairns MR, Gonzalez PA, Whiteford LM, Mihelcic JR. Emerging challenges for pathogen control and resource recovery in natural wastewater treatment systems. WIREs Water. 2015;2: 701-714. doi:10.1002/wat2.1101

3. Sarkar DJ, Das Sarkar S, Das BK, Sahoo BK, Das A, Nag SK, et al. Occurrence, fate and removal of microplastics as heavy metal vector in natural wastewater treatment wetland system. Water Res. 2021;192: 116853. doi:10.1016/j.watres.2021.116853

4. Machado R, Serralheiro R. Soil Salinity: Effect on Vegetable Crop Growth. Management Practices to Prevent and Mitigate Soil Salinization. Horticulturae. 2017;3: 30. doi:10.3390/horticulturae3020030

5. Algosaibi AM, El-Garawany MM, Badran AE, Almadini AM. Effect of Irrigation Water Salinity on the Growth of Quinoa Plant Seedlings. J Agric Sci. 2015;7. doi:10.5539/jas.v7n8p205

6. Isiordia Ge D, Torres Lc V, Moreno Ka G, Lizarraga A R, Macias M, Sánchez Á. Evaluation of the effect of the salinity of irrigation water on the yield of castor plant hybrids (Ricinus communis L.) in Mexico. Int J Hydrol. 2018;2. doi:10.15406/ijh.2018.02.00133

7. Navarro P. Natural Wastewater Treatment. Public Work Manag Policy. 2000;4: 177-183. doi:10.1177/1087724X0043002

8. Szabó A, Osztoics A, Szilágyi F. Natural wastewater treatment in Hungary. Water Sci Technol. 2001;44: 331-338. doi:10.2166/wst.2001.0848

9. Duan R, Fedler CB. Performance of a Combined Natural Wastewater Treatment System in West Texas. J Irrig Drain Eng. 2010;136: 204-209. doi:10.1061/(ASCE)IR.1943-4774.0000154 
10. Khoso S, Wagan H, Tunio H, Ansari A. An overview on emerging water scarcity in Pakistan, its causes, impacts and remedial measures. Istraz i Proj za privredu. 2015;13: 35-44. doi:10.5937/jaes13-6445

11. Reis M, Coelho L, Santos G, Kienle U, Beltrão J. Yield response of stevia (Stevia rebaudiana Bertoni) to the salinity of irrigation water. Agric Water Manag. 2015;152: 217-221. doi:10.1016/j.agwat.2015.01.017

12. Bernstein L. Effects of Salinity and Sodicity on Plant Growth. Annu Rev Phytopathol. 1975;13: 295-312. doi:10.1146/annurev.py.13.090175.001455

13. Niu G, Sun Y, Hooks T, Altland J, Dou H, Perez C. Salt Tolerance of Hydrangea Plants Varied among Species and Cultivar within a Species. Horticulturae. 2020;6: 54. doi:10.3390/horticulturae6030054

14. Huang L, Wu D, Zhang G. Advances in studies on ion transporters involved in salt tolerance and breeding crop cultivars with high salt tolerance. J Zhejiang Univ B. 2020;21: 426-441. doi:10.1631/jzus.B1900510

15. Liang W, Ma X, Wan P, Liu L. Plant salt-tolerance mechanism: A review. Biochem Biophys Res Commun. 2018;495: 286-291. doi:10.1016/j.bbrc.2017.11.043

16. Flowers TJ, Colmer TD. Plant salt tolerance: adaptations in halophytes. Ann Bot. 2015;115: 327-331. doi:10.1093/aob/mcu267

17. Flowers TJ, Colmer TD. Salinity tolerance in halophytes*. New Phytol. 2008;179: 945-963. doi:10.1111/j.14698137.2008.02531.x

18. Adlian A, Kurniasih B, Indradewa D. Effect of saline irrigation method on the growth of rice (Oryza sativa L.). Ilmu Pertan (Agricultural Sci. 2020;5: 19. doi:10.22146/ipas.24892

19. Ninmanont $P$, Wongchai $C$, Pfeiffer W, Chaidee A. Salt stress of two rice varieties: root border cell response and multi-logistic quantification. Protoplasma. 2021;258: 1119-1131. doi:10.1007/s00709-021-01629-x

20. Hanin M, Ebel C, Ngom M, Laplaze L, Masmoudi K. New Insights on Plant Salt Tolerance Mechanisms and Their Potential Use for Breeding. Front Plant Sci. 2016;7. doi:10.3389/fpls.2016.01787

21. Awan S, Ippolito JA, Ullman JL, Ansari K, Cui L, Siyal AA. Biochars reduce irrigation water sodium adsorption ratio. Biochar. 2021;3: 77-87. doi:10.1007/s42773-020-00073-z

22. Xiao K, Liang S, Wang X, Chen C, Huang X. Current state and challenges of full-scale membrane bioreactor applications: A critical review. Bioresour Technol. 2019;271: 473-481. doi:10.1016/j.biortech.2018.09.061

23. Tasić ŽZ, Bogdanović GD, Antonijević MM. Application of natural zeolite in wastewater treatment: A review. J Min Metall A Min. 2019;55: 67-79. doi:10.5937/JMMA1901067T

24. B S, Gunjalli G, S A, Priya M C. Performance Efficiency of the Zeolite Synthesized from Fly Ash in Wastewater Treatment. Int J Eng Technol. 2018;7: 819. doi:10.14419/ijet.v7i3.12.16509

25. Ospanov K, Myrzakhmetov M, Andraka D, Dzienis L. APPLICATION OF NATURAL ZEOLITE FOR INTENSIFICATION OF MUNICIPAL WASTEWATER TREATMENT. J Ecol Eng. 2016;17: 57-63. doi:10.12911/22998993/65446

26. Garcia RA, Vanelli CP, Pereira Junior O dos S, Corrêa JO do A. Comparative analysis for strength serum sodium and potassium in three different methods: Flame photometry, ion-selective electrode ( $<\mathrm{scp}>\mathrm{ISE}</ \mathrm{scp}>$ ) and colorimetric enzymatic. J Clin Lab Anal. 2018;32. doi:10.1002/jcla.22594

27. Mohammadi Z, Shalavi S, Jafarzadeh H. Ethylenediaminetetraacetic acid in endodontics. Eur J Dent. 2013;07: S135-S142. doi:10.4103/1305-7456.119091

28. Sattari MT, Feizi H, Colak MS, Ozturk A, Apaydin H, Ozturk F. Estimation of sodium adsorption ratio in a river with kernelbased and decision-tree models. Environ Monit Assess. 2020;192: 575. doi:10.1007/s10661-020-08506-9

29. Alavi N, Zaree E, Hassani M, Babaei AA, Goudarzi G, Yari AR, et al. Water quality assessment and zoning analysis of Dez eastern aquifer by Schuler and Wilcox diagrams and GIS. Desalin Water Treat. 2016;57: 23686-23697. doi:10.1080/19443994.2015.1137786

30. Thu TH, Huong TTT, Trung DT. Study on the relationship between total dissolved solids (TDS) and electrical conductivity (EC) of the aquifers in Ca Mau province. Tạp chí Khoa học và Công nghệ biển. 2019;19: 303-311. doi:10.15625/1859$3097 / 19 / 2 / 11087$ 
31. Rusydi AF. Correlation between conductivity and total dissolved solid in various type of water: A review. IOP Conf Ser

Earth Environ Sci. 2018;118: 012019. doi:10.1088/1755-1315/118/1/012019

32. Taylor M, Elliott HA, Navitsky LO. Relationship between total dissolved solids and electrical conductivity in Marcellus hydraulic fracturing fluids. Water Sci Technol. 2018;77: 1998-2004. doi:10.2166/wst.2018.092

33. Thirumalini S, Joseph K. Correlation between Electrical Conductivity and Total Dissolved Solids in Natural Waters. Malaysian J Sci. 2009;28: 55-61. doi:10.22452/mjs.vol28no1.7

34. Yogafanny E, Yohan KO, Sungkowo A. Treatment of brackish groundwater by zeolite filtration in Sumur Tua Wonocolo, 401 Kedewan, Bojonegoro, East Java. IOP Conf Ser Earth Environ Sci. 2018;212: 012014. doi:10.1088/1755-1315/212/1/012014 